\title{
A colorimetric method for the determination of carboxyhaemoglobin over a wide range of concentrations
}

\author{
P. TRINDER AND F. E. HARPER \\ From the Biochemistry Department, Central Laboratory, Royal Infirmary, Sunderland, and the Biochemistry \\ Department, Central Laboratory, General Hospital, Middlesbrough
}

SYNOPSIS A colorimetric technique for the determination of carboxyhaemoglobin in blood is described. Carbon monoxide released from blood in a standard Conway unit reacts with palladous chloride/arsenomolybdate solution to produce a blue colour. Using 0.5 to $2 \mathrm{ml}$. of blood, the method will estimate carboxyhaemoglobin accurately at levels from $0.1 \%$ to $100 \%$ of total haemoglobin and in the presence of other abnormal pigments.

A number of methods are available for the determination of carboxyhaemoglobin; none is accurate below a concentration of $1.5 \mathrm{~g}$. carboxyhaemoglobin per $100 \mathrm{ml}$. but for most clinical purposes this is not important. For forensic purposes and occasionally in clinical use, an accurate $\mathscr{O}$ determination of carboxyhaemoglobin below $750 \mathrm{mg}$. per $100 \mathrm{ml}$. may be required and no really ? satisfactory method is at present available. Some time ago when it was important to know whether a person who was found dead in a burning house had died before or after the fire had started, we became interested in developing a method which would determine accurately carboxyhaemoglobin at levels of $750 \mathrm{mg}$. per $100 \mathrm{ml}$.

\section{EXPERIMENTAL}

Carbon monoxide reduces palladous chloride to metallic palladium, releasing an equivalent amount of hydrochloric acid. The acid produced can be titrated (Conway, 1957) or the palladous chloride left in solution can be measured (Gray and Sandiford, 1946) but neither determination is sufficiently sensitive for the measurement of microlitre volumes of carbon monoxide.

It occurred to us that it might be possible to dissolve the metallic palladium film in arsenomolybdic acid, thereby producing the characteristic blue colour of the reduced acid. Such a colour reaction did take place in the presence of strong sulphuric acid, but the results obtained were too erratic to be of much value. However, it was observed that the palladium film did not form when carbon monoxide reacted with a mixture of palladous chloride and arsenomolybdic acid; instead a stable blue colour resulted. The colour developed from a given volume of carbon monoxide released from carboxyhaemoglobin was very constant, and a method was worked out for the determination of carboxyhaemoglobin in $0.5 \mathrm{ml}$. to $2.0 \mathrm{ml}$. samples of blood, using standard Conway microdiffusion units. A somewhat similar reaction taking place in a silica gel medium containing silicomolybdic acid and palladous sulphate

Received for publication 22 June 1961. was used for the estimation of carbon monoxide in air by the indicator tube method developed by Shepherd (1947). This reaction does not take place in an aqueous? medium. Sodium formate was used to release standard volumes of carbon monoxide, owing to the difficulty? of preparing stable standard solutions of carboxy- 0 haemoglobin. The colour developed from $0.01 \mathrm{ml}$. carbon monoxide evolved from sodium formate is $\delta$ somewhat erratic. The colour developed is constant when $0.1 \mathrm{ml}$. carbon monoxide is released and sodium 0 formate equivalent to this amount is used as a standard.

\section{METHOD}

REAGENTS The following were used:-

Arsenomolybdic acid (Nelson, 1944) Ammonium N molybdate, $25 \mathrm{~g}$., is dissolved in $450 \mathrm{ml}$. of water; $21 \mathrm{ml}$. of concentrated sulphuric acid is added, followed $\omega$ by $3 \mathrm{~g}$. of sodium arsenate, $\mathrm{Na}_{2} \mathrm{HAsO}_{4} \cdot 7 \mathrm{H}_{2} \mathrm{O}$, dissolved in $25 \mathrm{ml}$. of water. The mixture is incubated at $37^{\circ} \mathrm{C}$. for 48 hours and then stored in a brown bottle.

Palladium chloride solution 0.02N Palladium chloride, $\stackrel{\infty}{+}$ $0.88 \mathrm{~g}$., $\mathrm{PdCl}_{2}$, is dissolved in $500 \mathrm{ml}$. of $0.01 \mathrm{~N} \mathrm{HCl}$.

Colour reagent Just before use 3 volumes of arseno-음 molybdic acid are mixed with 1 volume of $0.02 \mathrm{~N}$ pallad-尺 ium chloride.

Sulphuric acid $4 N$ 
Sulphuric acid concentrated $(98 \% \mathrm{w} / \mathrm{w})$

Sodium formate $0.152 \% w / v 0.2 \mathrm{ml}$. is equivalent to $0.1 \mathrm{ml}$. of $\mathrm{CO}$ at N.T.P.

PROCEDURE The colour reagent, in $2 \mathrm{ml}$. amounts, is placed in the inner chamber of each of three standard Conway units. In the outer chamber of the first unit (test), $0 \cdot 5$ to $2 \mathrm{ml}$. of blood (made up to $2 \mathrm{ml}$. with water), is placed, tilting the unit and allowing only the lower half to be wetted. In the outer chamber of the second unit (blank) $2 \mathrm{ml}$. of water is placed. The outer chamber of the third unit (standard) contains $0.2 \mathrm{ml}$. of $0.152 \%$ sodium formate which has been evaporated to dryness in a vacuum desiccator. To the outer chambers of the first and second units $0.25 \mathrm{ml}$. quantities of $4 \mathrm{~N}$ sulphuric acid are added, ensuring that the blood and acid do not mix. To the outer chamber of the third unit $2 \mathrm{ml}$. of concentrated sulphuric acid is added, avoiding the area occupied by the sodium formate. After affixing the lids, which are well greased with soft white paraffin, the contents of the outer chambers are mixed with a gentle swirling action. The seal between the lid and the chamber should be a continuous transparent ring, and is maintained by a weight of approximately $2 \mathrm{lb}$. (1 kg.) placed on each lid. After standing for 18 hours or longer at room temperature, the contents of each inner chamber are transferred quantitatively, using a teat and capillary pipette and $5 \times 0.5 \mathrm{ml}$. quantities of wash water, to $5 \mathrm{ml}$. glass stoppered cylinders, except for the standard which is normally diluted $\times 10$, i.e., to $50 \mathrm{ml}$. After making up to volume, the optical densities of the test and standard are read, after setting a photoelectric absorptiometer to zero with the blank. Cells of $10 \mathrm{~mm}$. optical path and the Chance OR1 filter are used. If a spectrophotometer is used a wavelength setting of 670 to $735 \mathrm{~m} \mu$ is suitable, the absorption maximum

TABLE I

OPTICAL DENSITIES OF SOLUTIONS CONTAINING INCREASING AMOUNTS OF CARBOXYHAEMOGLOBIN

\begin{tabular}{cl} 
COHb Present (mg.) & Optical Density \\
\hline 3.7 & $0 \cdot 37$ \\
$7 \cdot 4$ & $0 \cdot 74$ \\
$14 \cdot 7$ & $0 \cdot 74 \times 2$ \\
$29 \cdot 4$ & $0 \cdot 74 \times 4$ \\
$44 \cdot 1$ & $0 \cdot 75 \times 6$ \\
$58 \cdot 8$ & $0 \cdot 74 \times 8$ \\
$73 \cdot 5$ & $0.735 \times 10$
\end{tabular}

being 730 to $735 \mathrm{~m} \mu$. Large optical densities are determined by diluting the test and blank solutions with water, to give optical densities in the range 0.2 to 0.8 (Table I). The optical density of the diluted solution is then multiplied by the dilution factor. Using the OR1 filter the standard diluted 1 in 10 gives an optical density reading in the region of 0.75 .

$$
\begin{aligned}
& \text { g. carboxyhaemoglobin per } 100 \mathrm{ml} \text {. blood } \\
& =\frac{100 \times 0.073}{\text { ml. blood used }} \times \frac{\text { O.D. of test }}{\text { O.D. of standard }}
\end{aligned}
$$

where $0.073=\mathrm{g}$. of haemoglobin combining with $0.1 \mathrm{ml}$. of $\mathrm{CO}$ (the volume liberated by the standard). Since the O.D. of the standard is about $0.75 \times 10=7.5$, using $2 \mathrm{ml}$. of blood optical densities of 0.2 to 7.5 will correspond to 0.1 to $3.65 \mathrm{~g}$. carboxyhaemoglobin per $100 \mathrm{ml}$. of blood, i.e., $0.7 \%$ to $25 \%$ of the total haemoglobin when the latter is $14.6 \mathrm{~g}$. per $100 \mathrm{ml}$. If the level of carboxyhaemoglobin is greater than $3.65 \mathrm{~g}$. per $100 \mathrm{ml}$., $0.5 \mathrm{ml}$. of blood is used and the same optical density range will then cover carboxyhaemoglobin levels of $0.4 \mathrm{~g}$. to $14.6 \mathrm{~g}$. per $100 \mathrm{ml}$. of blood, i.e., $2.8 \%$ to $100 \%$ of the total haemoglobin when the latter is $14.6 \mathrm{~g}$. per $100 \mathrm{ml}$. The carboxyhaemoglobin in the test is calculated as a percentage of the total haemoglobin after estimating the latter by the cyanmethaemoglobin method, allowing the diluted blood to stand overnight to ensure the complete conversion of carboxyhaemoglobin to cyanmethaemoglobin. With some post-mortem specimens containing abnormal blood pigments, it may be necessary to estimate the total iron content of the blood, to obtain an accurate estimation of the total haemoglobin.

The blue solution strictly obeys Beer's law over a range of optical density up to $8 \cdot 0$, using appropriate dilutions to bring the measured optical densities to less than $0 \cdot 8$.

The undiluted blue solution is stable indefinitely, but the solution diluted 1 in 10 slowly fades.

\section{RESULTS}

The speed of the reaction was studied using 0.5 and $2 \mathrm{ml}$. quantities of blood and the sodium formate standard. The results shown in Table II indicate that the reaction is virtually complete after 16 hours at room temperature.

Table III shows the results of replicate analyses on samples containing small and large quantities

TABLE II

RATE OF COLOUR DEVELOPMENT

$\begin{array}{llll}\begin{array}{l}\text { Reaction Time } \\ \text { (hr.) }\end{array} & \begin{array}{l}0.5 \mathrm{ml} . \text { Blood Sample } \\ (\mathrm{COHb}=100 \% \text { total } \mathrm{Hb})+1.5 \mathrm{ml} .\end{array} & \begin{array}{l}2.0 \mathrm{ml} . \text { Blood Sample } \\ (\mathrm{COHb}=5 \% \text { of total } \mathrm{Hb})\end{array} & \begin{array}{l}\text { Standard } \\ (0 \cdot \mathrm{l} \mathrm{ml} \text { of CO at N.T.P. })\end{array}\end{array}$

Optical Density

\begin{tabular}{rlll}
\multicolumn{7}{c}{ Optical Density } \\
\hline 4 & $0.445 \times 10(62 \%)^{1}$ & $0.285 \times 4(60 \%)$ & $0.415 \times 10(57 \%)$ \\
8 & $0.595 \times 10(83 \%)$ & $0.405 \times 4(85 \%)$ & $0.635 \times 10(87 \%)$ \\
16 & $0.715 \times 10(100 \%)$ & $0.465 \times 4(98 \%)$ & $0.715 \times 10(98 \%)$ \\
24 & $0.715 \times 10$ & $0.475 \times 4$ & $0.730 \times 10$
\end{tabular}

${ }_{1}$ Figures in parentheses are expressed as $\%$ of the 24 -hr. values 
TABLE III

REPLICATE ANALYSES

$0.5 \mathrm{ml}$. Blood of High COHb Content $+1.5 \mathrm{ml}$. Water

\begin{tabular}{clll}
\hline No. of Analyses & \multicolumn{4}{l}{ COHb\% Total $\mathrm{Hb}$} \\
\cline { 2 - 4 } & Mean & Range & S.D. \\
\hline 10 & 94 & $91-96$ & 1.8
\end{tabular}

$2 \cdot 0 \mathrm{ml}$. Pooled Normal Blood

No. of Analyses $\quad \mathrm{COHb} \%$ Total $\mathrm{Hb}$

Mean Range S.D.

12

$1 \cdot 26$

$1 \cdot 19-1 \cdot 31$

0.037

TABLE IV

RECOVERY OF CARBOXYHAEMOGLOBIN ADDED TO BLOOD

$0.5 \mathrm{ml}$. Blood $+1.5 \mathrm{ml}$. Water

\begin{tabular}{ccr}
\hline $\begin{array}{l}\text { COHb Added } \\
(\% \text { of total } \mathrm{Hb})\end{array}$ & $\begin{array}{l}\text { COHb Recovered } \\
(\% \text { of total Hb) }\end{array}$ & $\%$ Recove \\
\hline 2.5 & $2 \cdot 5$ & 100 \\
5.0 & $4 \cdot 7$ & 94 \\
8.0 & $8 \cdot 1$ & 101 \\
10.0 & $9 \cdot 6$ & 96 \\
20.0 & 19.6 & 98 \\
25.0 & 24.8 & 99 \\
40.0 & 41.5 & 104 \\
50.0 & 50.0 & 100 \\
80.0 & 82.0 & 103 \\
100.0 & 100.0 & 100
\end{tabular}

$2 \mathrm{ml}$. Blood

COHb Added COHb Recovered $\%$ Recovery

( \% of total $\mathrm{Hb}$ )

( $\%$ of total $\mathrm{Hb}$ )

$\begin{array}{rrr}1.00 & 1.00 & 100 \\ 2.00 & 2.02 & 10 \\ 5.00 & 4.95 & 9 \\ 20.00 & 20.40 & 102\end{array}$

TABLE V

RESULTS ON SMOKERS AND NON-SMOKERS

\begin{tabular}{|c|c|c|c|c|}
\hline & \multicolumn{4}{|c|}{ Middlesbrough } \\
\hline & \multicolumn{4}{|c|}{$\mathrm{COHb} \%$ of Total $\mathrm{Hb}$} \\
\hline & No. & Mean & Range & S.D. \\
\hline $\begin{array}{l}\text { Non-smokers } \\
\text { Smokers }\end{array}$ & $\begin{array}{c}24^{1} \\
3\end{array}$ & $\begin{array}{l}0 \cdot 64 \\
3 \cdot 77\end{array}$ & $\begin{array}{l}0 \cdot 25-0 \cdot 95 \\
3 \cdot 2-4 \cdot 8\end{array}$ & 0.20 \\
\hline
\end{tabular}

Sunderland

$\mathrm{COHb} \%$ of Total $\mathrm{Hb}$

No. Mean Range S.D.

$23 \quad 0.90$

$0 \cdot 4-2 \cdot 1$

0.34

0.90
$2 \cdot 63$

$0 \cdot 7-6 \cdot 5$

$1 \cdot 62$

'All children

of carboxyhaemoglobin. The coefficient of variation is about $2 \%$ at high levels and $3 \%$ at low levels.

It was not found possible completely to remove carboxyhaemoglobin from blood samples, but recovery experiments on normal blood, to which carboxyhaemoglobin had been added, gave very satisfactory results (Table IV).

The results obtained from analyses of blood from smokers and non-smokers in Middlesbrough and Sunderland are shown in Table V.

\section{DISCUSSION}

The method gives very reproducible results over the whole range of carboxyhaemoglobin concentrations likely to be encountered in clinical and forensic practice. It is particularly suitable for the determina- tion of low concentrations of carboxyhaemoglobin or for the analysis of samples containing abnormal pigments which would interfere with direct 5 spectrophotometric methods. Its only disadvantage $>$ is that the reaction is slow and overnight standing? is required before the colour is fully developed. N For the purposes for which the method was developed this is no disadvantage.

We are grateful to the ward sisters at the Royal Infirmary, Sunderland, who gave us information about the smokinge habits of their patients.

\section{REFERENCES}

Conway, E. J. (1957). Microdiffusion Analysis and Volumetric Error, 4th ed., p. 327. Crosby Lockwood, London.

Gray, C. H., and Sandiford, M. (1946). Analyst, 71, 107.

Nelson, N. (1944). J. biol. Chem., 153, 375.

Shepherd, M. 1947). Anal. Chem., 19, 77. 